\title{
PERSEPSI TOKOH MASYARAKAT TERHADAP ASPEK POLITIK EKSISTENSI PEKERJA SEKS KOMERSIAL (PSK) DI EKS LOKALISASI RAWA LAUT PANJANG SELATAN BANDAR LAMPUNG
}

\author{
M.SIDI RITAUDIN \\ Universitas Islam Negeri Raden Intan Lampung \\ Jln. Endro suratmin, sukarame, Bandar Lampung \\ m.sidiritaudin@radenintan.ac.id
}

Diterima: 10032019 Disetujui: 10062019 Dipublikasikan: 23062019

\begin{abstract}
This study aims to reveal perceptions of community leaders on the political aspects of the existence of commercial sex workers (PSK) in the former South Long Sea Swamp Localization. Bandar Lampung. Social insecurity caused by discriminatory government policies and lack of partiality towards people who are marginalized in social life has until now become a kind of destiny of life. Power is always always, will get challenges, rejection and lack of trust. The choice for power certainly carries a number of risks. One mandate in carrying out power is to favor the interests of the community and the public interest above personal or group interests. This was revealed in a preliminary study in an interview with the head of $R T 13$ Environment 1 Kelurahan Panjang Selatan that social inequality was due to inequality in policy making by the government. The political aspect of the existence of commercial sex workers (CSWs) in the former south long localization questioned the background that caused the powerlessness of the government in dealing with this problem.
\end{abstract}

Abstrak: Penelitian ini bertujuan untuk mengungkap persepsi tokoh masyarakat terhadap aspek politik eksistensi pekerja seks komersial (psk) di eks Lokalisasi Rawa Laut Panjang Selatan. Bandar Lampung. Kerawanan sosial yang disebabkan oleh kebijakan pemerintah yang 


\section{Sidi Ritaudin: PERSEPSI TOKOH MASYARAKAT.....}

diskriminatatif dan sepi dari keberpihakan terhadap orang-orang yang termarginalisasi pada kehidupan sosial, hingga kini telah menjadi semacam takdir kehidupan. Kekuasaan selalu saja, akan mendapatkan tantangan, penolakan sekaligus kekurangpercayaan. Pilihan untuk berkuasa tentu saja membawa sejumlah resiko. Salah satu amanah dalam mengemban kekuasaan adalah memihak kepentingan masayarakat dan kepentingan umum di atas kepentingan pribadi atau golongan. ${ }^{1}$ Hal ini terungkap dalam studi pendahuluan pada wawancara dengan ketua RT 13 Lingkungan 1 Kelurahan Panjang Selatan bahwa ketimpangan sosial terjadi karena ketimpangan pengambilan kebijakan oleh pemerintah. Aspek politik eksistensi pekerja seks komersial (PSK) di eks lokalisasi panjang selatan mempertanyakan latarbelakang yang menyebabkan ketidakberdayaan pemerintah dalam menangani masalah ini

\section{Key World : Aspek Politik, Eksistensi PSK, Lokalisasi, Persepsi.}

\section{A. Pendahuluan}

Salah satu aspek permasalahan sosial yang selalu aktual untuk didiskusikan adalah masalah pelacuran, karena persoalan ini sudah ada sejak jaman kerajaan dan jaman penjajahan di seluruh Indonesia sudah ada. Mulai dari dahulu sampai sekarang masalah pelacuran adalah masalah sosial yang sangat sensitif yang menyangkut peraturan sosial, moral, etika, bahkan agama. Pekerja seks komersial (PSK) merupakan problem sosial karena perbuatannya tidak bermoral dan merusak tatanan sosial masyarakat, serta menodai sakralisasi hubungan seksual.

Aspek politik eksistensi pekerja seks komersial (PSK) di eks lokalisasi panjang selatan mempertanyakan latarbelakang yang menyebabkan ketidakberdayaan pemerintah dalam

1 "Baca, "Kritik dan Tirani Kekuasaan", dalam Moh. Mahfud, dkk (ed.), Kritik Sosial dalam Wacana Pembangunan, Yogyakarta : Pusat Penerbitan UII Press, 1997), h. xii.," . 


\section{Sidi Ritaudin: PERSEPSI TOKOH MASYARAKAT.....}

menangani masalah ini, padahal kondisi objektif kota Bandar Lampung dapat didiskripsikan sebagai pintu gerbang sumatera, kota yang dihuni oleh pluralisme penduduk dan agama, tempat bertumpuknya barang perdagangan dan jasa. Hal ini tentu saja dapat menimnbulkan kerawanan sosial, di antaranya adalah menjadi kota transit narkoba, paham radikal, adanya kesenjangan yang sangat tajam antara si kaya dan si miskin, sikap individualisme yang pada akhirnya dapat mengendorkan semangat persatuan dan kesatuan bangsa.

Daerah Panjang Selatan, adalah daerah Pelabuhan Panjang hingga saat ini tercatat sebagai pelabuhan yang tetap menjadi eks lokalisasi di Indonesia contohnya beberapa seperti pelabuhan Tanjung Perak di Surabaya, pelabuhan Pulai Baai di Bengkulu, pelabuhan Ratu di Sukabumi, dan dipelabuhan Panjang di Bandar Lampung. Pelabuhan Panjang yang berada di Bandar Lampung itu sendiri yang bisa dikenal dengan PMD (Pemandangan). PMD yang betempat dikampung Rawa Laut, kelurahan Panjang Selatan itu terkenal sebagai kampung eks lokalisasi di kota Bandar Lampung, mengingat sebelum era kepemimpinan Wali Kota Bandar lampung Nurdin Muhayat, kawasan tersebut pernah dilegalkan oleh Pemerintah Kota Bandar Lampung sebagai salah satu perkampungan lokalisasi (selain lokalisasi Pemandangan di Way Lunik, Teluk Betung Selatan). Perda Kota Bandar Lampung Nomor 15 Tahun 2002 tentang Larangan Perbuatan Prostitusi dan Tuna Susila dalam Wilayah Kota Bandar Lampung menjadikan dua kawasan lokalisasi itu harus ditutup secara resmi.

Meskipun secara resmi sesuai dengan perda 15 tahun 2002 lokalisasi tersebut sudah ditutup, ironisnya aktivitas di dalamnya terus berlangsung hingga kini. Setiap Pekerja Seks Komersial (PSK) ketika itu diberikan identitas kartu kuning oleh 


\section{Sidi Ritaudin: PERSEPSI TOKOH MASYARAKAT.....}

pemerintah, tapi pada era Wali Kota Nurdin Muhayat, perkampungan ini tidak lagi mendapatkan dukungan dari pemerintah sebagai kawasan lokalisasi. Namun aktivitas perdagangan seks pun terus berlanjut, meskipun secara hukum kawasan tersebut telah dicabut status sebagai lokalisasi resmi, namun seperti ada kesepakatan tak tertulis, untuk saling melindungi satu dengan lainnya, sehingga suasana malam masih terus menyala dan membara hingga saat ini di kampung itu.

Menurut Selo Sumardjan masyarakat adalah orang-orang yang hidup bersama dan menghasilkan kebudayaan, oleh karena perilaku menyimpang yang lazim disebut sebagai penyakit masyarakat, termasuk aktivitas pekerja seks komersial (PSK) di eks lokalisasi pantai harapan ini yang berada di Kelurahan Panjang Selatan Bandar Lampung, jika tidak diberi wawasan untuk "move on", merubah mind set mereka, maka lama kelamaan menjadi budaya, yang tidak sesuai dengan budaya bangsa yang berasaskan Pancasila. Pemerintah Kota (Pemkot) Bandar Lampung, Lampung yang sudah melakukan inspeksi mendadak (Sidak) di Eks Lokalisasi pantai harapan Panjang. Sidak dilakukan, menyusul rencana pemulangan para pekerja seks komersial (PSK), sebagaimana program Pemerintah Provinsi Lampung bebas lokalisasi tahun 2017.

Sidak dipimpin langsung oleh Walikota Bandar Lampung Herman HN dan Wakil Walikota Bandar Lampung Abdul Kohar bersama kepala satuan kerja (Satker) terkait. Rombongan menyisir wisma-wisma karaoke yang selama ini menjadi ajang prostitusi terselubung. Setelah melihat-lihat wisma, walikota bersama rombongan kemudian mengajak dialog Ketua RT dan Ketua RW bersama tokoh masyarakat di bawah Area eks Lokalisasi. Ngobrol santai tersebut untuk mencari solusi nasib para mucikari dan masyarakat pascapemulangan para PSK. Masyarakat yang ada di sini keinginannya apa. Atau mungkin ada penawaran solusi dari 


\section{Sidi Ritaudin: PERSEPSI TOKOH MASYARAKAT.....}

masyarakat. Kalau dari Pemerintah Kota Bandar Lampung sendiri sudah ada solusi, yaitu mengajak dialog, supaya pemerintah tahu solusi terbaik, Program Penelitian ini berpretensi menindaklanjuti program-program yang telah digariskan oleh Wali Kota dan Wakil Walikota Bandar Lampung, dalam mencari solusi dimaksud.

Generasi muda (termasuk eks PSK) pada dasarnya memainkan peranan penting sebagai warga negara dalam masyarakat dan sistem politik. Dimasa depan generasi muda akan menjadi penduduk aktif yang perlu dipersiapkan pengetahuan politiknya sehingga mereka akan mempunyai kesadaran dan tindakan yang efektif secara politik. Baik-buruknya perlakuan terhadap generasi muda saat ini akan menentukan sehat tidaknya pelaksanaan demokrasi bangsa di masa yang akan datang.

Pada saat pra survey dan wawancara dengan pak Eko terungkap bahwa target pemerintah pada tahun 2021 mendatang seluruh kawasan eks lokalisasi di Kelurahan Panjang Selatan akan diratakan dengan tanah dan akan dibangun ruang terbuka hijau untuk tempat wisata. Rencana ini telah menimbulkan keresahan bagi sebahagian warga yang sudah bertahun-tahun tinggal di sana dan mereka takut kehilangan lahan dan mata pencahariannya. ${ }^{2}$

Mantan pelacur yang ingin kembali hidup ditengah-tengah masyarakat menginginkan harga dirinya kembali seperti saat belum menjadi pelacur. Salah satu tempat yang dipergunakan untuk memberikan bimbingan kepada mantan PSK, yaitu Dinas Sosial Propinsi Lampung. Melalui program Exceed (Eliminate Exploitive Child Labour through Education and Economics Develepmen)di Lampung di Tahun 2010 Dari hasil pra survey di lokasi, agaknya

2 "Wawancara dengan Pak Eko, Rt 13 Rawa Laut, Panjang Selatan tanggal 6 Oktober 2017. Menjadi buah pikirannya adalah akan pindah ke mana, apa akan dapat tempat tinggal dan pekerjaan baru, sementara umur sudah tua, anak mau sekolah.,". 


\section{Sidi Ritaudin: PERSEPSI TOKOH MASYARAKAT.....}

PSK yang berusia antara 34 sampai usia 40 tahun mendominasi PSK yang tinggal di eks lokalisasi Pemandangan Kelurahan Panjang Selatan dengan jumlah 58 orang atau 59,18\% dari jumlah PSK yang ada. Kemudian berikutnya PSK yang berusia antara 25 sampai usia 33 tahun sebanyak 25 orang atau $25,51 \%$ dari jumlah PSK yang ada, dan sebanyak 15 orang atau 15,31\% PSK yang berusia dibawah 25 tahun. Dari jumlah PSK di atas ada sebagian kecil yang telah meninggalkan pekerjaannya sebagai wanita penghibur dengan memilih menikah dan kembali ke masyarakat.

Berdasarkan data di atas terlihat angka perbandingan jumlah PSK yang masih aktif pada pekerjaannya dengan PSK yang memilih menikah dan kembali ke masyarakat. Dari ke tiga golongan usia PSK diatas, yang berusia dari 34 sampai 40 tahun lebih banyak telah meninggalkan pekerjaannya sebagai PSK sebesar $16,66 \%$ atau sebanyak 17 orang. Kemudian yang berusia antara 25 sampai 33 tahun sebesar 11,76\% atau sebanyak 12 orang dan tidak ada satupun yang dibawah usia 25 tahun memilih menikah dan kembali ke masyarakat. Mantan pelacur yang ingin kembali dalam masyarakat dan ingin hidup normal berada dalam suatu dilema.

Seperti halnya seseorang yang pernah menjadi pelacur merasa kesulitan menerima keberadaan dirinya yang telah menjalani kehidupan hitam. Ike (2006) berpendapat bahwa masih banyak perempuan-perempuan yang pernah menjadi pelacur sulit menerima keberadaan dirinya dan memilih hidup mengucilkan diri dari lingkungan masyarakat. Biasanya, mantan pelacur yang sulit menerima keberadaan dirinyaa dalah pelacur -pelacur yang dipaksa orang lain untuk menjadi pelacur, atau dijerumuskan oleh seseora ng menjadi pelacur. Mantan pelacur yang terpaksa menjadi pelacur ini akan merasa dirinya telah menjadi manusia kotor, merasa menjadi manusia yang kurang memiliki moral, menyalahkan diri sendiri, dan cenderung tidak akan menyenangi dirinya sendiri. 


\section{Sidi Ritaudin: PERSEPSI TOKOH MASYARAKAT.....}

Keadaan mantan pelacur yang tidak dapat menerima masa lalunya bahwa ia pernah sebagai pelacur akan mengalami kesulitan dalam penyesuaian diri dengan masyarakat.

Pada sisi lain seseorang wanita mantan pelacur atau mantan PSK tidak ubahnya sama dengan manusia pada umumnya, mereka juga mempunyai keinginan untuk berumah tangga atau berkeluarga bahagia secara normal. Proses penemuan suatu cita-cita ini bukanlah suatu perjalan yang mudah bagi seseorang mantan PSK, perjalanan untuk dapat menemukan tujuan apa yang mereka berikan dalam hidup mereka. Adapun mantan PSK diekslokalisasi di Kampung Rawa Laut Kelurahan Panjang Selatan ini yang mampu menyesuaikan diri terhadap masyarakat karena masyarakat sekitar ekslokalisasi memandang bahwa para PSK itu sendiri tidak memahami kenapa jalan itu yang harus mereka pilih. Pelacur juga manusia, mereka punya hati bahkan ada juga pelacur yang lebih baik dari pada orang yang mencemoohnya.

Meskipun ada sebagian masyarakat yang menghormati mantan PSK, namun masyarakat sekitar enggan bergaul dengan mantan PSK dan lebih memilih membatasi diri dengan mereka. Maka dari itu mantan PSK itu harus dapat membuktikan dia ingin benar-benar berubah dan bertaubat sebagai manusia lainnya hidup berkeluarga seperti sebelum dia menjadi seorang PSK. Bertitik tolak dari latar belakang permasalahan diatas maka peneliti bermaksud mengkaji Apa Aspek Politik Eksistensi Aktivitas PSK PSK dan Mantan PSK di Eks Lokalisasi Panjang Selatan Kota Bandar Lampung, Bagaimana Persepsi Masyarakat terhadap Aspek Politik Eksistensi PSK dan Mantan PSK yang Telah Berkeluarga Di Eks Lokalisasi Panjang Selatan Kota Bandar Lampung, dan Bagaimana Upaya PSK dan Mantan PSK Membina Hubungan Baik dengan Masyarakat Sekitar Di Ekslokalisasi Panjang Selatan Kota Bandar Lampung 


\section{Sidi Ritaudin: PERSEPSI TOKOH MASYARAKAT.....}

\section{B. Metode Penelitian}

Penulisan ini menggunakan dua pendekatan yaitu pendekatan yuridis normatif dan pendekatan yuridis empiris. Sumber data yang digunakan dalam penelitian ini adalah data lapangan dan data kepustakaan. Analisis terhadap data yang diperoleh dilakukan dengan cara analisis kualitatif yaitu analisis yang dilakukan secara deskriptif, kemudian hasil analisis tersebut dilanjutkan dengan menarik kesimpulan secara deduktif.

\section{Hasil dan Pembahasan}

\section{Seputar Wacana PSK}

Mempersoalkan dan membahas masalah sosial, termasuk masalah pelacuran atau sekarang lazim disebut sebagai Pekerja Seks Komersial (PSK), tentu saja berbagai teori ilmu pengetahuan dapat dihadirkan, semakin banyak teori yang sigunakan meniscayakan hasil penelitiannya akan semakin komprehensif. Menurut Koentjoro dan Sugihastuti ${ }^{3}$ bahwa pelacuran adalah orang yang melacurkan diri atau menjual diri. Istilah pelacur dianggapnya lebih tepat dibandingkan dengan Wanita Tuna Susila (WTS) dan Pekerja Seks Komersil (PSK), karena : Istilah pelacur sudah biasa di dengar di masyarakat, sehingga dapat digunakan untuk laki- laki dan perempuan yang melacurkan diri; Arti pelacur baik secara denotatif dan konotatif lebih lengkap dan spesifik dan dapat memberikan makna ganda; Tidak semua pelacur adalah pekerja seks; Istilah pekerja seks dapat diartikan sebagai pengakuan bahwa melacur merupakan peker-jaan.Tidak hanya itu, PSK juga dipandang sebagai problem seksual karena pelampiasan nafsu seks terhadap lawan jenis yang tidak terkendali.

3 “'Lestari, R. dan Koentjoro. 2002. Pelatihan berpikir optimis untuk meningkatkan harga diri pelacur yang tinggal dipantai dan luar pantai sosial. Jurnalilmiah berkala psikologi indigenous, (vol 6, no 2, 2002), h. 112.," . 


\section{Sidi Ritaudin: PERSEPSI TOKOH MASYARAKAT.....}

Suatu aktivitas seksual yang dilakukan dengan banyak orang. Akibat dari perbuatan tersebut, PSK dan bahayanya bagi masyarakat dihadapakan pada masalah penyakit kelamin yang sangat membahayakan seperti HIV/AIDS.Praktik pelacuran menurut Geltungstrieb ${ }^{4}$ adalah distimulasi oleh atau dorongan untuk menuntut hak dan kompensasi, karena individu tidak pernah merasakan kehangatan, perhatian, dan kasih sayang orangtua atau familinya. Dicari kompensasi bagi kekosongan hatinya, dengan jalan melakukan intervensi aktif dalam bentuk relasi seksual yang ekstrem tidak terkendali, alias pelacuran. Menurut Kartono ${ }^{5}$ faktor utama membentuk perilaku melacurkan diri adalah faktor kemiskinan dan kepribadian. Faktor kemiskinan termasuk salah satu faktor perilaku melacurkan diri dimana kebutuhan yang semakin banyak dengan pelonjakan harga perekonomian serta tingginya tingkat keinginan hidup kemewahan dengan keadaan yang tidak memungkinkan ditambah sulitnya mendapatka pekerjaan layak dengan gaji yang tinggi. Faktor kepribadian yang dimaksudkan di sini adalah harga diri.

Adams dalam Koentjoro, juga menyatakan bahwa pelacuran disebabkan karena adanya penolakan dan tidak dihargai oleh lingkungan, kemiskinan serta mudahnya mendapat uang ketika melacur. Dalam hal ini adapun dampak dari kehidupan PSK yaitu memiliki efek di belakangnya, entah itu efek positif maupun negatif. Begitupun pelacuran, karena pelacuran merupakan perilaku yang menyimpang dari norma masyarakat dan agama, maka pelacuran hanya akan mengakibatkan efek negatif, antara lain: Menimbulkan dan menyebar luaskan penyakit kelamin dan kulit,

${ }^{4}$ Kartini Kartono, Kamus Lengkap Psikologi, (Jakarta: Raja Grafindo Persada, 2002), h. 209.

${ }^{5}$ Kartini Kartono, Patologi sosial, (Jakarta: PT. Raja Grafindo Persada, 2003), t.t., .h.164. 


\section{Sidi Ritaudin: PERSEPSI TOKOH MASYARAKAT.....}

terutama syphilis dan gonorrhoe [kencing nanah]; Merusak sendisendi kehidupan keluarga. Suami-suami yang tergoda oleh pelacur biasanya melupakan fungsinya sebagai kepala keluarga, sehingga keluarga bmenjadi berantakan; Mendemoralisasikan atau memberikan pengaruh memoralisasi kepada lingkungan khususnya anak-anak muda pada masa puber dan adolesensi; Berkolerasi dengan kriminalitas dan kecanduan bahan-bahan narkotika; Merusak sendi-sendi moral, susila, hukum, dan agama; Dapat menyebabkan terjadinya disfungsi seksual ${ }^{6}$

Pada umumnya masyarakat menstigma negatif terhadap PSK berdasarkan ukuran moralitas, kesusilaan dan doktrin agama. Dasar kehidupan tersebut dianggap sebagai aturan yang asasi dan tidak boleh dilanggar dalam kondisi apapun. Baik secara kultural maupun sosial, PSK dikonstruksi sebagai sampah masyarakat Sampah merupakan simbol untuk melambangkan sesuatu yang jelek, kotor, menjijikkan dan tidak berguna. Sebutan terhadap PSK pun sangat bervariasi, seperti lonte, mahkluk rendahan, tuna susila dan semacamnya ${ }^{7}$ Diperjelas oleh Jamaluddin ${ }^{8}$ bahwa banyaknya langgganan yang dilayani oleh para wanita tuna susila ialah $5-50$ orang, dalam jangka waktu $12-24$ jam. Bahkan di waktu-waktu perang dan masa-masa kisruh, mereka itu mampu melayani 6 - 120 langganan dalam waktu yang sama. Pelacur-pelacur ini bisa digolongkan dalam dua kategori, yaitu:

6 “Eko, Eko Lusjianto, ”Hubungan antara Relegius dengan Prilaku Seksual Remaja yang sedang Pacaran", dalam Skripsi, (Tidak diterbitkan : 2015), h. 2. Lihat hhtp://digilib.itb.ac.idgdl.php?mod=browser\&op=read\&id= jiptumm-gdlsl-2002eko2cn-5756\&q=Remaja,"

7 Jamaluddin Mahfuzh, Psikologi Anak Dan Remaja Muslim, penerjemah Abdul Rosyad shiddiq (Jakarta: Pustaka Al-kautsar, 2001).

${ }^{8}$ Mahfuzh, 28. 


\section{Sidi Ritaudin: PERSEPSI TOKOH MASYARAKAT.....}

1. Mereka yang melakukan profesinya dengan sadar dan suka rela berdasarkan motivasi-motivasi tertentu, dan

2. Individu yang melakukan tugas melacur karena ditawan atau dijebak dan dipaksa oleh germo-germo yang terdiri atas penjahat-penjahat, calo-calo, dan anggota-anggota organisasi gelap penjual wanita dan pengusaha bordil.

Akibat bujukan dan janji-janji manis, ratusan bahkan ribuan gadis-gadis cantik dipikat dengan janji akan mendapatkan pekerjaan terhormat dengan gaji besar. Namun pada akhirnya, mereka dimasukkan ke dalam rumah-rumah pelacuran yang dijaga dengan ketat, secara paksa, kejam, dan sadistis, dengan pukulan serta hantaman yang tidak berperi kemanusiaan.

Dijelaskan oleh Kartono ${ }^{9}$ akibat cap negatif pada pelacur timbul reaksi sosial pada masyarakat yang bersifat menolak, masa bodoh, dan acuh tak acuh. Sikap menolak dapat bercampur dengan rasa benci, ngeri, jijik, takut, dan marah. Sikap masyarakat ini menimbulkan terjadinya konflik-konflik dan kecemasankecemasan yang banyak diderita oleh para pelacur. Pelacur merasa harga dirinya dihinakan oleh banyak orang.

W.A. Bonger, dalam tulisannya, "Maatschappelijke Oorzaken der Prostitutie" menulis defenisi sebagai berikut; "Prostitusi ialah gejala kemasyarakatan dimana wanita menjual diri melakukan perbuatan-perbuatan seksual sebagai mata pencaharian." Jelas dinyatakan adanya peristiwa penjualan diri sebagai profesi atau mata pencaharian sehari-hari dengan jalan melakukan relasi-relasi seksual.

Selanjutnya, defenisi prostitusi dapat disimpulkan sebagai berikut; Prostitusi adalah bentuk penyimpangan seksual,

\footnotetext{
${ }^{9}$ Kartini Kartono, Patologi sosial, (Jakarta: PT. Raja Grafindo Persada, 2003), h.
} 166. 


\section{Sidi Ritaudin: PERSEPSI TOKOH MASYARAKAT.....}

dengan pola-pola organisasi impuls/dorongan seks yang tidak wajar dan tidak terintegrasi dalam bentuk pelampiasan nafsu-nafsu seks tanpa kendali dengan banyak orang (promiskuitas), disertai eksploitas dan komersialisasi seks yang impersonal tanpa afeksi sifatnya; Prostitusi merupakan peristiwa penjualan diri (persundalan) dengan jalan menjualbelikan badan, kehormatan, dan kepribadian kepada banyak orang untuk memuaskan nafsu-nafsu seks dengan imbalan pembayaran; Prostitusi ialah perbuatan perempuan atau laki-laki yang menyerahkan badannya untuk berbuat cabul secara seksual dengan mendapatkan upah.

Dengan adanya komersialisasi dan barter seks, perdagangan atau tukar-menukar seks dengan benda bernilai, maka pelacuran merupakan profesi yang paling tua sepanjang sejarah kehidupan manusia. Sedangkan akibat yang timbul dari aktivitas pelacuran dapat bersifat negatif maupun positif. Akibat negatif jauh lebih banyak daripada akibat positinya. Akibat negatif, yaitu akibat yang menimbulkan dan menyebarluaskan bermacam-macam penyakit kotor dan menular yang sangat berbahaya, yakni penyakit akibat hubungan kelamin atau penyakit hubungan seksual (PHS).

Dalam bidang moral, susila, hukum dan agama, pekerjaan pelacuran termasuk demoralisasi (tidak bermoral), Yang bergaul intim dengan mereka juga demoralisasi, karena itu masyarakat memandang rendah martabat wanita pelacur. Pelacuran juga dapat menimbulkan kriminalitas dan kecanduan bahan narkotika, karena di tempat-tempat pelacuran biasanya adalah tempat berkumpulnya para penjahat profesional yang berbahaya dan orang-orang yang sedang ber-masalah dengan keluarga atau masalah yang lain. Selain di bidang kesehatan dan moral, pelacuran dapat juga mengakibatkan eksploitasi manusia oleh manusia yang lain, karena umumnya wanita-wanita pelacur itu hanya menerima upah sebagian kecil saja dari pendapatan yang harus diterimanya. 


\section{Sidi Ritaudin: PERSEPSI TOKOH MASYARAKAT.....}

Sebagian besar pendapatannya harus diberikan kepada germo, para calo, centeng, dan sebagainya. Apabila dilihat dari akibat berbahayanya, gejala pelacuran merupakan gejala sosial yang harus ditanggulangi, sekalipun masyarakat menyadari bahwa sejarah membuktikan sangat sulit memberntas dan menang-gulangi masalah pelacuran, karena ternyata makin banyak tipe-tipe pelacuran yang ada dalam masyarakat. ${ }^{10}$

Prostitusi, pelacuran atau yang kini lazim disebut sebagai Pekerja Seks Komersial (PSK), termasuk dalam kategori Patologi Sosial. Dalam kehidupan masyarakat, selalu terdapat penyimpangan-penyimpangan sosial yang dilakukan oleh anggota, baik yang dilakukan secara sengaja maupun terpaksa. Fenomena tersebut tidak dapat dihindari dalam sebuah masyarakat, karena perilku menyimpang ini sudah ada semenjak adanya peradaban manusia. Interaksi sosial yang terjadi di antara anggota masyarakat terkadang menimbulkan kesalahpahaman yang tidak jarang terjadi penyimpangan norma yang berlaku pada masyarakat tersebut. Seperti diketahui, bahwa interaksi manusia tidak saja berwujud interaksi dengan sesamanya tetapi juga interaksi dengan lingkungan. Dalam wujud yang luas, interaksi dengan lingkungan bisa berbentuk interaksi anggota masyarakat dengan berbagai budaya, gaya hidup, dan kondisi regional yang sedang berlaku di sebuah negara di mana masyarakat itu bernaung. Bisa berbentuk kondisi perekonomian, kondisi keamanan, kebijakan pemerintah, dan sebagainya.

Di antara penyimpangan sosial yang banyak terdapat di hampir seluruh negara adalah prostitusi. Tak salah lagi, prostitusi selalu ada dalam kehidupan masyarakat sejak ribuan tahun yang lalu. Seks dan wanita adalah dua kata kunci yang terkait dengan

${ }^{10}$ Artikel "Pelacuran sebagai Masalah Sosial” dalam www.academia.edu. diposting pada Desember 2013, diakses pada 9 januari 2015. 


\section{Sidi Ritaudin: PERSEPSI TOKOH MASYARAKAT.....}

prostitusi. Seks adalah kebutuhan manusia yang selalu ada dalam diri manusia dan bisa muncul secara tiba-tiba. Seks juga bisa berarti sebuah ungkapan rasa abstrak manusia yang cinta terhadap keindahan. Sedangkan wanita adalah satu jenis makhluk Tuhan yang memang diciptakan sebagai simbol keindahan. Maka fenomena yang sering terjadi di masyarakat adalah seks selalu identik dengan wanita. Namun, celakanya lagi, yang selalu menjadi korban dari keserakahan seks adalah juga wanita.

Lebih jauh, sebagai asumsi dasar, dapat dikatakan bahwa kehidupan wanita dalam dunia seks (prostitusi), bisa terjadi karena dua faktor utama yaitu "faktor internal" dan "faktor eksternal". Faktor internal adalah yang datang dari individu wanita itu sendiri, yaitu yang berkenaan dengan hasrat, rasa frustrasi, kualitas konsep diri, dan sebagainya. Sedangkan faktor eksternal adalah sebab yang datang bukan secara langsung dari individu wanita itu sendiri melainkan karena ada faktor luar yang mempengaruhinya untuk melakukan hal yang demikian. Faktor eksternal ini bisa berbentuk desakan kondisi ekonomi, pengaruh lingkungan, kegagalan kehidupan keluarga, kegagalan percintaan, dan sebagainya.

\section{Jasa Prostitusi dan Seks}

Prostitusi adalah penjualan jasa seksual, seperti oral seks atau hubungan seks, untuk uang. Seseorang yang menjual jasa seksual disebut pelacur, yang kini sering disebut dengan istilah pekerja seks komersial (PSK). Atau prostitusi adalah salah satu patologi sosial yang merupakan keroyalan relasi seksual dalam bentuk penyerahan diri untuk pemuasan seksual dan dari perbuatan tersebut yang bersangkutan dengan imbalan. ${ }^{11}$ Disamping itu prostitusi dapat diartiakan dengan salah satu tingkah laku yang tidak susila atau gagal untuk menyesuaikan diri dengan normanorma susila. oleh sebab itu, pelacur yang melakukan royal dan

${ }^{11}$ http://kesmas-ode.blogspot.com/2012/11/prostitusi_3010.html 


\section{Sidi Ritaudin: PERSEPSI TOKOH MASYARAKAT.....}

tidak pantas, berhubungan seks dengan orang yang tidak terbatas, maka pada dirinya sering mendatangkan penyakit yang dapat berjangkit dalam dirinya maupun kepada orang lain. Prostitusi merupakan tingkah laku lepas dan bebas tanpa kendali serta mengandung tindak pelampiasan nafsu tanpa mengenal batas kesopanan. Prostitusi selalu ada pada semua Negara yang berbudaya, sejak zaman purbakala sampai sekarang. Keberadaannya selalu mejadi masalah dan patologi sosial, objekobjek hukum, dan tradisi. Dengan berkembangnya teknologi, industri dan kebudayaan manusia, prostitusi berkembang sejalan dengan proses tersebut dalam berbagai bentuk dan tingkatan.

Peristiwa prostitusi timbul akibat adanya dorongan seks yang tidak terintergrasi dengan kepribadian pelakunya. Dari impuls-impuls seks yang tidak terkendali oleh hati nurani tersebut dipakailah teknik seksual yang kasar dan provokatif dan berlangsung tanpa afeksi an perasaan emosi serta kasih sayang. Serta adanya masalah kemiskinan yang mendorong seseorang melakukan postitusi.

Perbuatan prostitusi dilakukan sebagai kegiatan sambilan atau pengisi waktu senggang, ataupun sebagai pekerjaan penuh (profesi). Pada tahun 60-an dinas sosial menggunakan istilah wanita tuna susila (WTS) bagi pelacur wanita sedangkan pelacur pria disebut gigolo.

Perubahan sosial yang diakibatkan oleh perkembangan tehnologi, ilmu pengetahuan serta komunikasi di dunia dewasa ini akan mempengaruhi kebiaaan hidup manusia. Disamping itu sekaligus mempengaruhi pola-pola seks yang konvensional (menurut adat yang berlaku). Pelaksanaan seks banyak dipengaruhi oleh penyebab perubahan sosial antara lain : urbanisasi, mekanisasi, alat kontrasepsi, pendidikan, demokratisasi fungsi wanita dalam masyarakat dan moderenisasi. Efek sampingan dari dampak tersebut adalah keluar dari jalur konvensional kultur. Bagi mereka 


\section{Sidi Ritaudin: PERSEPSI TOKOH MASYARAKAT.....}

yang tidak mampu menghayati kepuasan seks sejati, seks bebas tidak akan memperoleh kepuasan.

Pada umumnya di desa-desa tidak terdapat prostitusi, jika ada mereka merupakan pendatang dari kota. Di kota-kota jumlah prostitusi sekitar 1 sampai $2 \%$ dari jumlah penduduk. Jumlah tersebut sudah termasuk yang tersamar atau gelap atau bersifat non professional, dari tingkat bawah sampai tingkat tinggi. Mereka beroperasi bersempunyi-sembunyi secara individual atau bergabung dalam satu sindikat. Profesi prostitusi dijalankan dengan kondisi sebagai berikut. Melakukan profesinya secara sadar dan suka rela, berdasarkan motifasi tertentu. Dijebak dan dipaksa oleh germogermo yang terdiri dari penjahat, calo, anggota organissi gelap penjual wanita dan pengusaha bordil.

Fungsi prostitusi yaitu menjadi sumber eksploitasi bagi kelompok-kelompok tertentu, khususnya bagi mereka yang memberikan partisipasi. Pada umumnya masyarakat menolak adanya pelacuran, tetapi dalam kenyataannya mereka tidak bisa mengelak dan harus menerimanya. Kedudukan sosial pelacur sangat rendah, tugasnya memberikan pelayanan seks kepada kaum pria, namun demikian ada beberapa fungsi yang tergolong positif sifatnya, bagi masyarakat. Fungsi yang dimaksud dapat dijadikan katup pengaman yang secara jujur diakui, sebab dapat dijadikan sebagai berikut :

1. Sumber pelancar dalam dunia business.

2. Sumber kesenangan dari kaum yang harus berpisah dari istrinya.

3. Sumber hiburan individu atau kelompok

4. Sumber pelayanan dan hiburan bagi orang cacat (misalnya pria yang wajahnya buruk, pincang, abnormal seksualnya dan para penjahat).

Dalam menjalankan fungsinya para pelacur tersebut berlatar belakang menderita lemah mental, penghayal dan psikopat, atau dengan kata lain rohaninya tidak sempurna serta adanya 


\section{Sidi Ritaudin: PERSEPSI TOKOH MASYARAKAT.....}

kemiskinan dalam hidup. Oleh sebab itu, kehidupannya pada umumnya dihiasi dengan kemewahan semu berupa pakaian yang gemerlapan, makanan yang lezat dan berlimpah, berganti-ganti partner, tanpa ikatan, tanpa tanggung jawab.

\section{Akibat-Akibat Prostitusi}

Praktek-praktek prostitusi biasanya ditolak oleh masyarakat dengan cara mengutuk keras, serta memberikan hukuman yang berat bagi pelakunya. Namun, demikian ada anggota masyarakat yang bersifat netral dengan sikap acuh dan masa bodoh. Disamping itu ada juga yang menerima dengan baik. Sikap menolak diungkapkan dengan rasa benci, jijik, ngeri, takut dan lain-lain. Perasaan tersebut timbul karena prostitusi dapat mengakibatkan sebagai berikut. : Menimbulkan dan menyebarkan penyakit kelamin dan penyakit kulit. Penyakit kelamin tersebut adalah sipilis dan gonorrgoe. Keduanya dapat mengakibatkan penderitanya menjadi epilepsi, kelumpuhan, idiot psikotik yang berjangkit dalam diri pelakunya dan juga kepada keturunan; Merusak sendi-sendi kehidupan keluarga, sehingga keluarga menjadi berantakan; Memberi pengaruh demoralisasi kepada lingkungan, khususnya remaja dan anak-anak yang menginjak masa puber; Berkorelasi dengan kriminalitas dan kecanduan minuman keras dan obat terlarang (narkoba); Merusak sendi-sendi moral, susila, hukum dan agama; Terjadinya eksploitasi manusia oleh manusia lain yang dilakukan oleh germo, pemeras dan centeng kepada pelacur.; Menyebabkan terjadi disfungsi seksual antara lain : impotensi, anorgasme.

Belakangan ini ramai polemik tentang istilah pelacur menjadi PSK. Dalam setiap forum, kelompok liberal dan para pezinah kerap menggunakan istilah PSK dengan dalih berempati dengan wanita yang mencari nafkah untuk diri dan keluarganya. Sementara, kaum religius, menolak istilah PSK untuk mengganti dari kata pelacur, karena beranggapan PSK menjadi pekerjaan yang sah dikerjakan.Kupukupu 


\section{Sidi Ritaudin: PERSEPSI TOKOH MASYARAKAT.....}

malam, lonte, ayam kampus, jablay, perek, adalah sedikit banyak di antara istilah yang kerap terdengar dimasyarakat ketika menunjuk pada sesosok perempuan berprofesi pelacur. Kata pelacur ataupun lonte yang dulu sering digunakan untuk mengidentifikasikan pekerja seks, sungguh menambah stigma buruk terhadap profesi yang satu ini. Menarik, Ketua Indonesia Tanpa JIL (ITJ) Akmal Sjafril sampai menyebut penghalusan kata pelacur menjadi PSK sebagai bentuk 'Konspirasi” . Ia mempertanyakan, siapa sebenarnya yang pertama kali menggunakan istilah PSK, namun yang jelas, nampaknya semua media sudah bersepakat (atau berkonspirasi) untuk menggunakannya secara konsisten.

Kata PSK adalah sebuah istilah yang sangat kontradiktif. Bukan merupakan penghalusan, melainkan pengaburan makna yang sebenarnya. Selain pelacur dan PSK, kemudian berkembang istilah WTS (wanita tuna susila) karena menganggap bahwa perempuan yang melacurkan diri tidak menuruti aturan susila yang berlaku di masyarakat. Secara legal, pemerintah Indonesia mengeluarkan surat Keputusan Menteri Sosial No. 23/HUK/96 (dalam Koentjoro, 2003:65) yang menyebut pelacur dengan istilah WTS. Namun menurut Koentjoro (2003:45) upaya pemerintah saat itu sebenarnya tidak lain untuk melebih haluskan istilah pelacur. Adapun orang yang melakukan aktifitas prostitusi disebut Pekerja Seks Komersial (PSK) dikenal pula dengan nama Wanita Tuna Susila (WTS) Tuna Susila, diartikan sebagai; kurang beradab karena keroyalan relasi seksualnya, dalam bentuk penyerahan diri pada banyak laki-laki untuk pemuasan seksual dan mendapatkan imbalan jasa atau uang bagi pelayanannya. Tuna susila juga diartikan sebagai; salah tingkah, tidak susila atau gagal menyesuaikan diri terhadap norma-norma susila. Maka pelacur itu adalah wanita yang tidak pantas kelakuannya dan bisa mendatangkan petaka/celaka dan penyakit, baik kepada orang lain yang bergaul.

\section{a. Dampak Negatif Pelacuran Terhadap Biologis}




\section{Sidi Ritaudin: PERSEPSI TOKOH MASYARAKAT.....}

Bagi masyarakat barat hubungan pra-nikah bahkan gonta-ganti pasangan atau free seks adalah hal yang biasa, namun di negara Timur terutama Indonesia yang masih menjunjung tinggi norma agama, hal seperti itu adalah aib dan penyakit kelamin lainnya) yang ditimbulkan akibat melakukan pelacuran (freesex) muncul sebagai jawaban dari perilaku binatang yang tak layak dilakukan manusia, kehadirannya kini tak lebih dari malapetaka atau laknat. Berbagai penelitian menunjukkan bahwa AIDS adalah penyakit yang unik karena menyerang sistem kekebalan tubuh. Yang paling mengagetkan, hingga kini belum ditemukan obatnya dan siapa pun bisa terjangkit tak peduli orang kotor atau mereka yang baik-baik.

Penyakit kelamin juga sering menyerang orang yang melakukan free sex. Diantara pelacur atau pelaku free seks terjadi saling transfer penyakit. Sehingga semakin sering dia melakukannya, maka semakin rentan terhadap berbagai macam penyakit. Berbagai penyakit kelamin yang kini dikenal di dunia kedokteran diantaranya: sifilis, mole, gonore, ulkus, limprogranuloma, venereum, inguinale, trikomoniasis, herpes progenitalis, trikomoniasis dan AIDS (al-Ghifari, 2003:102).

\section{b. Dampak Negatif Pelacuran Terhadap Psikologis}

Beberapa akibat yang ditimbulkan oleh pelacuran menurut Kartini Kartono(2003:203);

a. Merusak sendi-sendi kehidupan keluarga. Suami-suami yang tergoda oleh pelacur biasanya melupakan fungsinya sebagai kepala keluarga, sehingga keluarga menjadi berantakan

b. Mendemolisir atau memberikan pengaruh demorilasi kepada lingkungan khususnya anak-anak muda remaja pada masa puber dan adolensi.

c. Berkorelasi dengan kriminalitas dan kecanduan bahan-bahan narkotika (ganja, morfin, heroin dan lain-lain) 


\section{Sidi Ritaudin: PERSEPSI TOKOH MASYARAKAT.....}

d. Merusak sendi-sendi moral, susila, hukum dan agama. Terutama sekali menggoyahkan norma perkawinan, sehingga menyimpang dari adat kebiasaan, norma hukum dan agama, karena digantikan dengan pola pelacuran dan promiskuitas; yaitu digantikan dengan pola pemuasan kebutuhan seks dan kenikmatan seks yang awut-awutan murah serta tidak bertanggung jawab. Bila pola pelacuran ini telah membudaya, maka rusaklah sendi-sendi kehidupan yang sehat.

e. Adanya pengeksploitasian manusia oleh manusia lain. Pada umumnya wanita-wanita pelacur itu Cuma menerima upah sebagian kecil saja dari pendapatan yang harus diterimanya, karena sebagian besar harus diberikan kepada germo, calocalo, centeng-centeng, pellindung dan lain-lain. Dengan kata lain, ada sekelompok manusia benalu yang memeras darah dan keringat para pelacur ini.

\section{c. Dampak Negatif Pelacur Berupa Sanksi Sosial}

1. Pelacur yang aktif mendapat cemooh dari kalangan masyarakat setempat.

2. Bukan hanya pelacur yang aktif mantan pelacur sekalipun sulit diterima kembali di kalangan masyarakat yang akibatnya matan pelacur banyak yang mengasingkan diri.

\section{Aspek Politik Eksistensi Aktivitas PSK dan Mantan PSK}

\section{a. Kebijakan Politik dalam Menanggulangi Masalah Sosial}

Prostitusi merupakan sesuatu yang merusak moral bangsa, meresahkan masyarakat pada umunya dan keluarga pada khususnya.Faktor perkembangan zaman atau globalisasi yang sangat besar pengaruhnya terhadap prostitusi mulai dari sifat materialisme sampai perkembangan teknologi.Peran pemerintah yang masih kurang dalam penanganan prostitusi, sehingga masih banyaknya tempat-tempat prostitusi yang legal di tiap-tiap daerah. Seharusnya ada suatu peraturan semacam 


\section{Sidi Ritaudin: PERSEPSI TOKOH MASYARAKAT.....}

UU tentang pelarangan tempat-tempat prostitusi, tapi sekarang prostitusi hanya berada dalam kewenangan daerah masingmansing dengan dikeluarkannya PERDA. Penyelesaian prostitusi membutuhkan diterapkannya kebijakan yang didasari syariat Islam. Harus dibuat undang-undang yang tegas mengatur keharaman bisnis apapun yang terkait pelacuran. Negara merupakan satu-satunya institusi yang mampu menerapkan syariat Islam ini dalam bentuk Khilafah Islamiyah, yang diharapkan bias membersihkan noda-noda prostitusi dalam Negara.

Pada aspek kesehatan disinyalir berdasarkan penelusuran sejarah menunjukkan bahwa antara tahun 19021912 dilaporkan bahwa ada sekitar 6,5\% orang Eropa, 5,47\% orang pribumi dan $13,11 \%$ orang Cina kejangkitan penyakit sipilis. Hal ini menunjukkan bahwa prostitusi adalah bagian kehidupan masyarakat kolonial, baik dari masyarakat pribumi sampai orang-orang Eropa. Bagi pelaku prostitusi, baik itu Pekerja Seks Komersial, mucikari, pengusaha, hingga pemilik warung, dan keamanan menganggap prostitusi adalah sebagai ladang ekonomi. Tempat untuk mencari nafkah. Di sinyalir oleh para ahli yang mengatakan bahwa ekonomi adalah salah satu faktor yang menjadi alasan seseorang terlibat pada dunia prostitusi atau pelacur. ${ }^{12}$

Faktor lain antara lain suami yang tidak tanggung jawab, keluarga yang tidak harmonis, dll. Bagi mereka pelacur sama saja dengan Mbut Gawe atau bekerja, Seksualitas di Jawa Pada Awal Abad XX ${ }^{13}$ dalam masyarakat juga dikenal

12 https://frahardi.wordpress.com/2016/06/14/persinggungan-politik-danprostitusi-dalam-puisi/

13 http://pspk.ugm.ac.id/seminar/69-seksualitas-di-jawapada-awal-abad$\mathrm{xx} \cdot \mathrm{html}$ 


\section{Sidi Ritaudin: PERSEPSI TOKOH MASYARAKAT.....}

istilah Lunga Sedelok Bondho Wis Ketok, maksudnya pergi sebentar harta sudah terlihat.

\section{b. Kebijakan Politik dalam Menanggulangi Masalah Prostitusi}

Dilihat dari aspek pendidikan, prostitusi merupakan kegiatan yang demoralisasi. Dari aspek kewanitaan, prostitusi merupakan kegiatan merendahkan martabat wanita. Dari aspek ekonomi, prostitusi dalam prakteknya sering terjadi pemerasan tenaga kerja. Dari aspek kesehatan, praktek prostitusi merupakan media yang sangat efektif untuk menularnya penyakit kelamin dan kandungan yang sangat berbahaya. Dari aspek kamtibmas praktek prostitusi dapat menimbulkan kegiatan-kegiatan kriminal Dari aspek penataan kota, prostitusi dapat menurunkan kualitas dan estetika lingkungan perkotaan

Pendekatan kemanusiaan terhadap masalah apa pun adalah suatu hal universal. Apalagi terhadap masalah yang sangat kental nuansa pelanggaran HAM-nya, seperti prostitusi. Selama ini pendekatan yang digunakan, khususnya oleh pemerintah, masih belum manusiawi. Untuk itu ada beberapa hal yang patut diperhatikan :

Pertama, pendekatan keamanan dan ketertiban yang legalistikformil dan militeristik, seperti yang digunakan aparat keamanan dan ketertiban (tramtib), tidak menyelesaikan masalah. Kalaupun dilakukan penertiban prostitusi, haruslah penertiban yang women-friendly dengan pendekatan kemanusiaan. Pendekatan dalam peerda adalah abolisionis yang memandang perempuan yang dilacurkan sebagai kriminal, padahal dia merupakan korban mata rantai sistemik feminisasi kemiskinan dan marjinalisasi perempuan. Konsep 


\section{Sidi Ritaudin: PERSEPSI TOKOH MASYARAKAT.....}

atau pendekatan penertiban haruslah memasukkan unsur-unsur HAM, termasuk dalam kurikulum pendidikan para polisi pamong praja atau aparat lain.

Kedua, penyelesaian persoalan harus sampai ke akar persoalan, holistik, dan integratif. Termasuk memberi penyadaran, mulai dari pola pikir aparat, masyarakat, rohaniwan, sampai sikap dan perilaku bahwa perempuan yang dilacurkan adalah korban. Bersama-sama kita bahu-membahu mencari solusi persoalan, memberi bekal para perempuan yang dilacurkan untuk menopang ekonomi keluarga berupa kemampuan baca- tulis, keterampilan rias wajah, menyamak kulit, menjahit, wirausaha, atau inisiatif lain yang patut dihargai dan didukung.

Ketiga, penggunaan berbagai istilah yang menyudutkan mereka, seperti sampah masyarakat, penyakit masyarakat, dan penyandang masalah kesejahteraan sosial, harus dihentikan. Stigmatisasi korban yang tercetus dalam penggunaan bahasa semacam ini yang juga termin dalam kebijakan pemerintah, harus dihapuskan.

Keempat, mulai sejak kurikulum pendidikan calon petugas tramtib, penggunaan pola militeristik yang menonjolkan kekerasan harus dihapus. Yang kemudian melakukan penertiban, diharapkan bukan hanya aparat laki-laki, tetapi juga perempuan dengan jumlah proporsional. Jangan kemudian mereka hanya menjadi pelengkap, apalagi "pajangan”. Karena perempuan yang dilacurkan rentan pelecehan seksual, maka perlindungan saksi pelapor juga diperlukan. Kerja sama dan pengawasan ketat bersama pemerintah daerah asal dalam pemulangan juga diperlukan untuk menghindari agar tidak semata-mata menjadi proyek pemulangan saja. 


\section{Sidi Ritaudin: PERSEPSI TOKOH MASYARAKAT.....}

\section{c. Kebijakan Politik berdasarkan Undang-Undang}

Dalam Convention for the Suppresion of the Traffic to Persons and of the Prostitution of Others tahun 1949, Konvensi Penghapusan Diskriminasi terhadap Perempuan (diratifikasi Pemerintah RI dengan Undang-Undang Nomor 7 Tahun 1984) dan terakhir pada bulan Desember 1993 oleh Perserikatan Bangsa-Bangsa (PBB), perdagangan perempuan serta prostitusi paksa dimasukkan sebagai bentuk "kekerasan terhadap perempuan". Hal ini menunjukkan pengakuan bersama komunitas internasional bahwa dalam prostitusi, apa pun bentuk dan motivasi yang melandasi, seorang perempuan yang dilacurkan adalah korban. Yang juga ironis adalah, dari berbagai pola pendekatan terhadap prostitusi, baik upaya penghapusan, sistem regulasi, atau pelarangan, perlindungan memadai akan hak sebagai individu dan warga negara para perempuan korban itu masih terabaikan. Perbuatan Protitusi adalah perbuatan yang dilakukan oleh siapapun baik laki-laki maupun perempuan yang menyediakan diri sendiri atau orang lain kepada umum untuk melakukan pelacuran, baik dengan imbalan jasa maupun tidak, Sedangkan Tuna Susila adalah seorang laki-laki/perempuan yang melakukan hubungan seks dengan lawan jenisnya secara berulang-ulang dengan bergantian pasangan diluar perkawinan yang syah dengan mendapat uang, materi atau jasa.

\section{d. Kebijakan Politik berdasarkan Aspek Agama.}

Bagi masyarakat umum kota Bandar Lampung yang mayoritas beragama Islam yang mengharamkan prostitusi, prostitusi dianggap mengancam. Menurut mereka, prostitusi adalah ladang penyakit kelamin, sumber kemaksiatan, dan merusak moral generasi muda. Atas alasan ingin mengangkat 


\section{Sidi Ritaudin: PERSEPSI TOKOH MASYARAKAT.....}

harkat perempuan, agar mereka bekerja dengan halal, pendidikan moral anak-anak dan remaja di sekitar lokalisasi. Oleh sebagian kalangan menilai bahwa langkah Nurdin Muhayat (Wali Kota Bandar Lampung kala itu) mengeluarkan Perda no 15 tahun 2002 untuk menutup kawasan lokalisasi di daerah Pemandangan, Rawa Laut Panjang Selatan ini dan langkah wali kota yang lain yang hendak menutup prostitusi dianggap pencitraan. Inilah kenapa prostitusi mengait juga di bidang politik. Sebagian masyarakat menginginkan prostitusi ditutup maka menutup prostitusi akan mendapat dukungan politik dan simpati dari masyarakat, Karena kenyataannya kawasan tersebut meski sudah ditutup sejak tahun 2002 hingga kini masih berlangsung.

e. Kebijakan Politik berdasarkan Aspek Kesehatan

Upaya penghapusan lokalisasi yang marak beberapa tahun terakhir perda (sejak diterbitkannya PERDA No.15 tahun 2002) justru membuat "kantung-kantung" prostitusi baru makin menyebar dan tak terpantau. Termasuk risiko terkena HIV/AIDS yang sulit dikontrol karena pemeriksaan rutin pada para perempuan yang dilacurkan di lokalisasi terhenti. Hakhak mereka atas pelayanan kesehatan yang memadai kian terabaikan. Apalagi jika diketahui, sebagai pengidap AIDS atau HIV positif, kekerasan yang dialami akan semakin berlipat, termasuk terhadap anggota keluarga korban, karena dalam dunia kesehatan juga menunjukkan dan memperingatkan bahaya penyakit kelamin yang mengerikan seperti HIV / AIDS akibat adanya pelacuran di tengah masyarakat.

5. Persepsi Masyarakat terhadap Aspek Politik Eksistensi PSK 


\section{Sidi Ritaudin: PERSEPSI TOKOH MASYARAKAT.....}

Persepsi Masyarakat terhadap Kebijakan Politik dalam Menanggulangi Masalah Sosial Pembinaan untuk membentuk keluarga yang harmonis merupakan penyelesaian jalur sosial yang juga harus menjadi perhatian pemerintah. Hal ini disebabkan keluarga merupakan salah satu pilar dalam masyarakat yang ikut menentukan kualitas suatu generasi. Negara wajib menjamin pendidikan untuk memberikan bekal kepandaian dan keahlian pada warganya. Hal ini terkait dengan poin kedua di atas, yakni agar setiap individu mampu bekerja dan berkarya dalam rangka memenuhi kebutuhan hidupnya dengan cara yang baik dan halal.

Dari dalil-dalil yang dikemukakan oleh para tokoh agama tersebut sangat jelas bahwa tidak ada toleransi untuk melindungi praktek prostitusi dengan membuat lokalisasi. Para tokoh masyarakat dari unsur agamis mempertanyakan masih berlangsungnya praktik prostitusi di eks lokalisasi Rawa Laut Panjang Selatan, pun demikian pula halnya yang masih terjadi praktik prostitusi di Kota Bandar Lampung yang tersembunyi seperti di hotel-hotel, SPA, cofe, Salon dan lain sebagainya. Dalam Islam, prostitusi disamakan dengan zina. Seddangkan zina menurut Islam, seperti dijabarkan dalam fiqih, ada tiga pendapat:

a. Menurut Syafi'iyah, zina adalah perbuatan lelaki memasukkan penisnya ke dalam liang vagina wanita lain (bukan isterinya atau budaknya) tanpa syubhat.

b. Menurut Malikiyah, zina adalah perbuatan lelaki menyenggamai wanita lain pada vagina atau duburnya tanpa syubhat.

c. Menurut Hanafiyah, ia adalah persenggamaan antara lelaki dan wanita lain di vaginanya, bukan budaknya dan tanpa syubhat. 


\title{
Sidi Ritaudin: PERSEPSI TOKOH MASYARAKAT.....
}

\begin{abstract}
Peraturan Pemerintah Daerah Provinsi Lampung mengenai penanggulangan masalah pelacuran, menyatakan sebagai berikut; Wanita tunasusila adalah wanita yang mempunyai kebiasaan melakukan hubungan kelamin di luar perkawinan, baik dengan imbalan jasa maupun tidak. Sedang pasal 296 KUHP mengenai prostitusi tersebut meyatakan sebagai berikut; Barang siapa yang pekerjaanya atau kebiasaanya, dengan sengaja mengadakan atau memudahkan perbuatan cabul dengan orang lain, dihukum dengan hukuman penjara selama-lamanya satu tahun empat bulan atau denda sebanyak-banyaknya seribu rupiah.
\end{abstract}

Jelasnya, pelacuran itu bisa dilakukan baik oleh kaum wanita maupun pria. Jadi, ada persamaan predikat lacur antara laki-laki dan wanita yang bersama-sama melakukan perbuatan hubungan kelamin di luar perkawinan. Dalam hal ini, perbuatan cabul tidak hanya berupa hubungan kelamin di luar nikah saja, akan tetapi termasuk pula peristiwa homoseksual dan permainan seksualnya.

\section{Kesimpulan}

Berdasarkan hasil penelitian yang telah dilakukan penulis mengenai Persepsi Tokoh Masyarakat Terhadap Aspek Politik Eksistensi Pekerja Seks Koimersial (PSK) Di Eks Lokalisasi Rawa Laut Panjang Selatan Bandar Lampung sebagai berikut:

1. Terdapat persepsi positif dan persepsi negatif dari tokoh masyarakat terhadap mantan psk di ekslokalisasi khusunya terkait dengan aspek politik keberadaan PSK di eks lokalisasi Kampung Rawa Laut. Terdapat persepsi positif yaitu menganggap baik dan memberikan nilai yang positif terhadap mereka. Pemerintah pun memberikan jalan keluar kepada mereka dengan memberikan program penyuluhan dan 


\section{Sidi Ritaudin: PERSEPSI TOKOH MASYARAKAT.....}

pelatihan agar mereka bisa meninggalkan profesi mereka sebagai pekerja seks komersial. Sedangkan persepsi negatif, tidak sedikit masyarakat justru mencibir dan melecehkan mereka yang mereka katakan bahwa mereka sebetulnya menikmati profesi mereka sebagai wanita lacur mencari uang dengan mudah tanpaa bekerja keras dan memotar otak hanya mengandalkan tubuh saja. Bahkan ada jijik dan menghindar jika mereka bertemu dengan wanita PSK ini dan menganggap mereka hanya mencari duit saja jika ada pogram dari pemerintah.

2. Kemudian upaya-upaya yang dilakukan oleh mantanPSK di eks lokalisasi Kampung Rawa Laut, Kecamatan Panjang Selatan Kota Bandar Lampung yakni membina hubungan baik dengan masyarakat sekitar, Mereka melakukan apasaja yang membuat masyarakat menerima kehadiran mereka mulai dari berkeluarga dengan menikah, mengikuti kegiatan sosial dan aktif mengikuti kegiatan keagamaan yang diadakan oleh masyarakat baik itu di rumah-rumah warga ataupun masjidmasjid yang ada disekitar mereka, kemudian dengan bekerja di rumah-rumah warga sebagai tukang cuci dan seterika pakaian, selanjutnya rajin memeriksakan diri agar bebas dari penyakit menular seksual (pms), dan rajin mengikuti penyuluhan dan keterampilan ketenagakerjaan yang diadakan oleh Dinas Sosial Kota Bandar Lampung.

3. Usaha-usaha yang dilakukan oleh eks psk ini dilakukan dengan sungguh-sungguh meskipun tidak sedikit yang mencemooh dan merasa jijik, atau bahkan menolak keberadaan mereka di tengah-tengah masyarakat. Akan tetapi tetap mereka lakukan agar mereka dapat kembali hidup normal sebagai makhluk sosial. Reaksi sosial terhadap mantan pekerja seks komersial di 


\section{Sidi Ritaudin: PERSEPSI TOKOH MASYARAKAT.....}

eks lokalisasi Kampung Rawa Laut, Kecamatan Panjang Selatan Kota Bandar Lampung, terlihat bahwa ada anggota masyarakat yang menolak kehadiran eks PSK ini ditengahtengah mereka. Hal ini dikarenakan mereka merasa jijik dan takut tertular oleh penyakit menular seksual yang bisa saja dibawa oleh mantan psk ini. Kemudian anggota masyarakat merasa lingkungan tempat tinggalnya tercemar nama baiknya karena keberadaan wanita eks psk di tengah-tengah mereka meskipun mantan PSK ini rajin memerikasakan kesehatan dirinya di klinik kesehatan agar masyarakat merasa nyaman berinteraksi dengan mereka. Kondisi seperti ini dipengaruhi oleh PSK yang masih aktif berpura-pura berkeluarga dengan membuka usaha salon kecantikan dan pijat tradisional agar pemerintah kota melegalkan transaksi prostitusi yang mereka jalankan. Sebenarnya pemerintah kota melalui Dinas Sosial Kota Bandar Lampung sedang berupaya memberikan penyuluhan dan pelatihan ketenagakerjaan kepada wanita eks PSK ini agar mereka bisa hidup mandiri dan kembali hidup normal dan menjadi anggota masyarakat.

\section{DAFTAR PUSTAKA}

Artikel "Pelacuran sebagai Masalah Sosial" dalam www.academia.edu., diposting pada Desember 2013, diakses pada 9 januari 2015.

Eko, Eko Lusjianto, "Hubungan antara Relegius dengan Prilaku Seksual Remaja yang sedang Pacaran", dalam Skripsi, (Tidak diterbitkan: 2015), h. $2 . \quad$ Lihat hhtp://digilib.itb.ac.idgdl.php?mod=browser\&op=read\&id= jiptumm-gdlsl-2002-eko2cn-5756\&q=Remaja,"

http://kesmas-ode.blogspot.com/2012/11/prostitusi_3010.html 


\section{Sidi Ritaudin: PERSEPSI TOKOH MASYARAKAT.....}

https://frahardi.wordpress.com/2016/06/14/persinggungan-politik-danprostitusi-dalam-puisi/

http://pspk.ugm.ac.id/seminar/69-seksualitas-di-jawapada-awal-abadxx.html

Kartono, Kartini Kamus Lengkap Psikologi, Jakarta, Raja Grafindo Persada, 2002.

Kartono, Kartini Patologi sosial, Jakarta, PT. Raja Grafindo Persada, 2003.

Mahfud, Moh. dkk (ed.), Kritik Sosial dalam Wacana Pembangunan, Yogyakarta, Pusat Penerbitan UII Press, 1997.

Mahfuzh, Jamaluddin Psikologi Anak Dan Remaja Muslim, penerjemah Abdul Rosyad shiddiq Jakarta, Pustaka Al-kautsar, 2001.

Kartono,Kartini Patologi sosial, Jakarta, PT. Raja Grafindo Persada, 2003.

R, Lestari, dan Koentjoro. 2002. Pelatihan berpikir optimis untuk meningkatkan harga diri pelacur yang tinggal dipantai dan luar pantai sosial. Jurnalilmiah berkala psikologi indigenous, (vol 6, no 2, 2002).

Wawancara dengan Pak Eko, Rt 13 Rawa Laut, Panjang Selatan tanggal 6 Oktober 2017. Menjadi buah pikirannya adalah akan pindah ke mana, apa akan dapat tempat tinggal dan pekerjaan baru, sementara umur sudah tua, anak mau sekolah.,". 